\title{
The Postobstructive Kidney. Observations
}

\section{on Nephron Function after the Relief \\ of $24 \mathrm{hr}$ of Ureteral Ligation in the Dog}

\author{
D. Danny Bercovitch, Leonard Kasen, Laurence BlanN, and \\ MARVIN F. LeVITT
}

From the Division of Renal Diseases, Department of Medicine, The Mount Sinai Medical School of the City University of New York, New York 10029, and the Division of Nephrology, Department of Medicine, and the Lady Davis Institute for Medical Research, Jewish General Hospital, Montreal, Canada

A B S T R A C T After the relief of 24 hr of complete
unilateral ureteral obstruction in the dog, the experi-
mental kidney is characterized by a decrease in filtration
rate and an increase in fractional and often absolute ex-
cretion of sodium before and after the administration of
mannitol. In the hydrated state, the failure to conserve
sodium is associated with increases in fractional free
water clearance and fractional sodium supply to water-
freeing sites signifying that the augmented sodium ex-
cretion is derived from a proximal source. In the hydro-
penic state there is decreased fractional free water reab-
sorption, and sometimes free water excretion, in the
postobstructive kidney. An early plateau in free water
reabsorption is associated with an increased fractional
excretion of sodium. These findings are attributed to the
early development of distal nephron impermeability to
water as a result of enhanced distal tubular supply and
transport of sodium. There is a decrease in maximal
tubular reabsorptive capacity (Tm) of glucose in the post-
obstructive kidney which is, however, less marked than
the decrease in filtration rate. The fall in filtration rate
is to some extent likely due to a dropping out of nephrons
from the circulation while the remaining nephrons are
hypoperfused. The magnitude of the sodium reabsorptive
defect is markedly exaggerated as the concentration of
nonreabsorbable solute (mannitol) in the glomerular per-
fusate is increased. It is concluded that the postobstruc-
tive increase in sodium excretion during mannitol ad-

This work was presented at the Annual Meeting of the Canadian Society for Clinical Investigation, 21 January 1970, Montreal, Canada. (1969. Clin. Res. 17: 671.)

Dr. Bercovitch's present address is The Jewish General Hospital, Montreal, Canada.

Received for publication 24 July 1970 and in revised form 17 December 1970. ministration is in part due to a limit in the capacity to reabsorb sodium against a concentration gradient in the proximal tubule.

\section{INTRODUCTION}

Obstruction of the urinary tract has been shown to have a variety of effects on renal function in man and dog. Many of the described abnormalities have included observations of excessive electrolyte excretion and/or impaired concentrating capacity during or after the period of obstruction. The predominant locus of damage has been variously assigned to both the proximal $(1,2)$ and distal (3-7) nephron. Suki, Eknoyan, Rector, and Seldin (8) in a study of unilateral chronic hydronephrosis in hydrated dogs have concluded that the major disturbance in the obstructive nephropathy is increased GFR (glomerular filtration rate) ${ }^{1}$ per nephron leading to decreased proximal tubular reabsorption of sodium and hyperperfusion of the distal nephron. They further suggested that back-diffusion of solute free water was impaired in the collecting duct and possibly in the descending limb of Henle's loop by anatomic disruption of medullary tissue thereby permitting excessive urinary dilution.

In most of the reported studies, the period of obstruction has varied from a week to several months resulting

\footnotetext{
${ }^{1}$ Abbreviations used in this paper: $\mathrm{CH}_{2} \mathrm{O}$, free water clearance; Cosm, solute clearance; GFR, glomerular filtration rate; $\mathrm{PAH}$, para-aminohippuric acid; PAS, periodic acidSchiff; POK postobstructive (experimental) kidney; $\mathrm{T}$, reabsorbed glucose; $\mathrm{T}^{\mathrm{c}} \mathrm{H}_{2} \mathrm{O}$, free water reabsorption; UKV, urinary potassium excretion; $\mathrm{UNa}$, urinary concentration of sodium; UNaV, urinary sodium excretion; Uosm, urinary solute concentration.
} 
in large falls in GFR which makes a comparison of data with a normal control kidney somewhat uncertain. As well, various degrees of gross anatomic change in the experimental kidney have been noted making it difficult to distinguish to what degree the described abnormalities have been due to anatomic distortion of the kidney and to what extent purely functional changes prevail. In order to overcome these limitations, a relatively brief period of $24 \mathrm{hr}$ of unilateral ureteral obstruction was selected-an interval in which there is neither gross nor microscopic change in the experimental kidney.

In the present experiments, patterns of electrolyte excretion and diluting or concentrating capacity were investigated in hydrated or hydropenic dogs before and during a progressive mannitol diuresis after the relief of obstruction.

Our findings indicate that after a single day of obstruction there is a defect in proximal tubular reabsorption of sodium resulting in enhanced fractional sodium supply to and transport by the distal nephron, that this defect is exaggerated when proximal sodium reabsorption is subjected to a gradient imposed by a mannitol load, and that the inability of the postobstructive kidney to conserve sodium is present despite decreased glomerular perfusion in surviving nephrons.

\section{METHODS}

17 experiments were carried out in female mongrel dogs weighing $15-25 \mathrm{~kg}$ and maintained on regular commercial diets. The effects of unilateral ureteral obstruction on renal function were studied during hydration and hydropenia. Dogs were lightly anesthetized with thiamylal sodium, and under aseptic conditions a suprapubic midline incision was made and the bladder exposed. Two silk ties were tightly placed around the right ureter near the ureterovesical junction causing complete ureteral obstruction and the abdomen was closed. Animals were then returned to their cages and were generally awake within $1 \mathrm{hr}$ after surgery. In the hydropenic studies, animals were kept without food or water for $20 \mathrm{hr}$ after ureteral ligation and were given $5 \mathrm{U}$ of vasopressin tannate in oil intramuscularly $12 \mathrm{hr}$ before the renal function studies were begun. In the hydrated studies, animals were allowed free access to water. $24 \mathrm{hr}$ after right ureteral obstruction, hydropenic animals were anesthetized with sodium pentobarbital and hydrated animals with chloralose and urethane. Priming doses of creatinine or inulin (and in some studies, para-aminohippuric acid [PAH]) were administered and followed by a sustaining infusion of these substances at concentrations sufficient to produce stable plasma levels. In the hydropenic studies, aqueous vasopressin, $50 \mathrm{mU} / \mathrm{kg}$ per $\mathrm{hr}$ was added to the sustaining infusion. The midline suprapubic incision was then reopened, the left ureter catheterized with polyethylene tubing and one or two control timed urine specimens collected. The right ureter was then incised above the site of obstruction resulting in a gush of clear urine. A catheter was inserted high into the decompressed ureter to avoid dead space errors. Timed urine specimens were simultaneously collected from each kidney at 10 - to 50 -min intervals depending on urine flow rate. Hepa- rinized arterial blood specimens were obtained at the midpoint of each collection period.

In the hydropenic series, after one or two baseline periods, $10 \%$ mannitol in $0.2 \% \mathrm{NaCl}$ or $10 \%$ glucose in $0.2 \% \mathrm{NaCl}$ was infused into a foreleg vein at progressively increasing rates. In the hydrated studies, animals received 1-2 liters of either 2.0 or $2.5 \%$ glucose in $0.2 \% \mathrm{NaCl}$. After hydration, $2.0 \%$ or $2.5 \%$ mannitol in $0.2 \% \mathrm{NaCl}$ was progressively infused. The experiments were carried out until urine flow rate failed to increase with further increases in the rate of infusion.

In six hydropenic studies, $7.5-12.5 \%$ glucose in $0.2 \%$ $\mathrm{NaCl}$, rather than mannitol, was used as the loading solute so that glucose $\mathrm{Tm}$ (maximal tubular excretory capacity) could be determined in each kidney. In three studies $\mathrm{Tm}$ determinations were made after slowly increasing plasma glucose levels so that it could be noted whether or not initial glycosuria occurred simultaneously in both kidneys. In these studies, a minimum of 20 min was allowed for equilibration of the plasma glucose level after each increase in the rate of glucose infusion. In three other studies, plasma glucose was raised relatively quickly in the early periods, and glucose determinations were made only after plasma glucose levels had exceeded $400 \mathrm{mg}$ per $100 \mathrm{ml}$.

Urine and plasma specimens were analyzed in all studies for $\mathrm{Na}, \mathrm{K}, \mathrm{Cl}$, and osmolality. In the studies of glucose $\mathrm{Tm}$, glucose was determined in plasma and urine using Glucostat Reagent. ${ }^{2}$ Urine dilutions generally ranged from 500 to 1000 . In some experiments, inulin and PAH were determined and in others, including all glucose $\mathrm{Tm}$ studies, creatinine was determined. Other determinations were performed using methods previously described from this laboratory (9).

The clearance of creatinine or inulin was used to represent GFR; the clearance of $\mathrm{PAH}$ was used to represent effective renal plasma flow. Filtered sodium load was estimated as GFR times plasma sodium concentration. No correction was made for the Donnan effect. Fractional sodium excretion was calculated as urinary sodium excretion (UNaV)/GFR times PNa. Solute clearance (Cosm), free water reabsorption $\left(\mathrm{T}^{\mathrm{c}} \mathrm{H}_{2} \mathrm{O}\right)$, and free water clearance $\left(\mathrm{CH}_{2} \mathrm{O}\right)$ were calculated in the usual way. Reabsorbed glucose (T) was calculated as GFR (cc/min) times plasma glucose concentration $(\mathrm{mg} / \mathrm{cc})$ - Uglucose V where Uglucose represents glucose concentration in urine $(\mathrm{mg} / \mathrm{ml})$ and $\mathrm{V}$ represents urine flow rate $(\mathrm{ml} / \mathrm{min})$. Tm glucose was taken as the mean of a variable number of determinations of $\mathrm{T}$ after this parameter had reached maximal values in that kidney and was relatively stable.

In two animals, renal biopsies from both kidneys were taken from 24 to $48 \mathrm{hr}$ after unilateral ureteral ligation. Part of the biopsy material was fixed in formalin, embedded in paraffin, and stained with hematoxylin and eosin and periodic acid-Schiff (PAS) stain for light microscopy. The remainder was fixed in buffered $2 \%$ osmium tetroxide and embedded in Epon in preparation for electron microscopy.

\section{RESULTS}

Pathology. Longitudinal section of the control and experimental kidneys did not reveal any gross differences in the renal papillae or pelvi-calyceal systems.

Light microscopic sections in one of the postobstructive kidneys were entirely normal. In the second ex-

\footnotetext{
${ }^{2}$ Worthington Biochemical Corp., Freehold, N. J.
} 

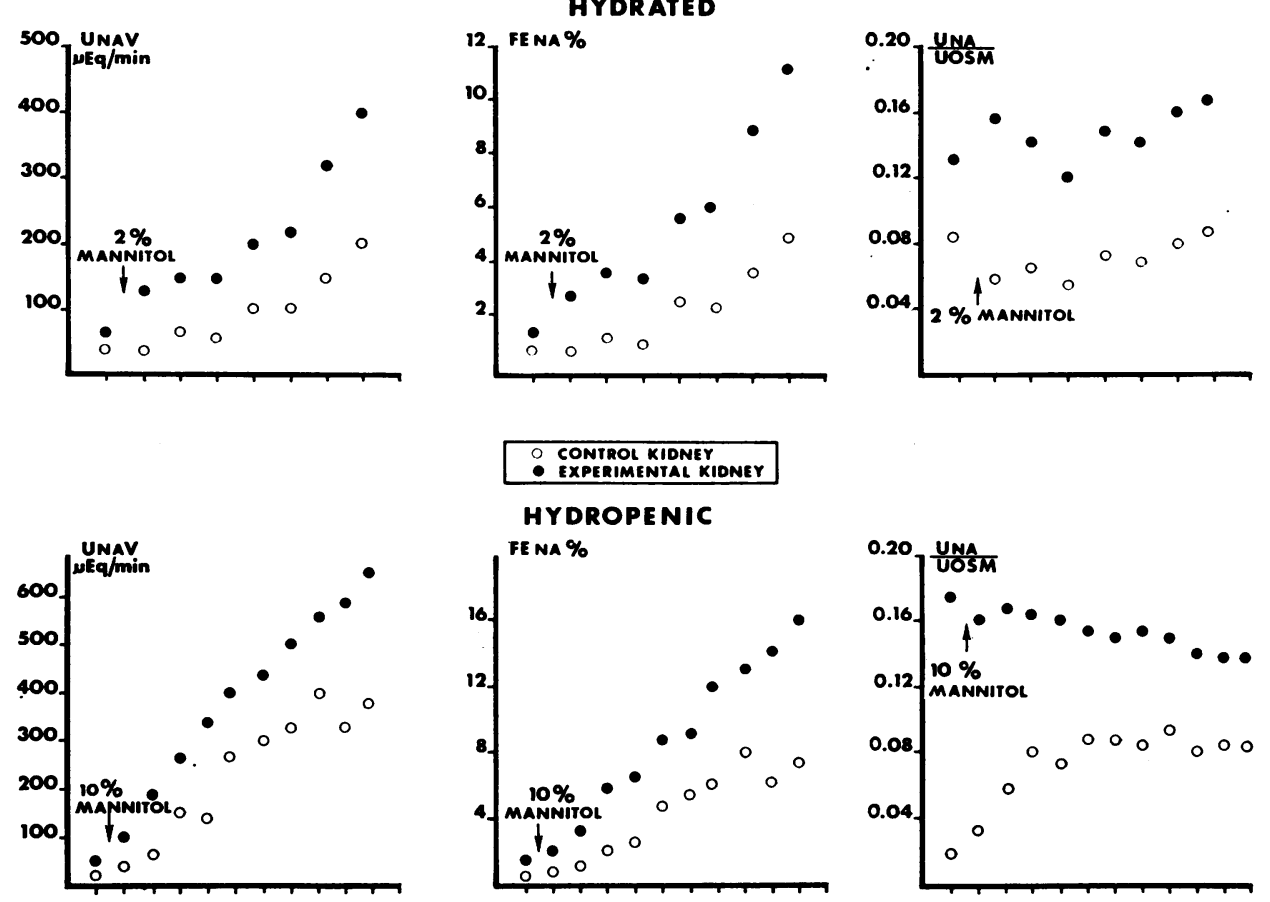

FIgURE $1 \mathrm{UNaV}, \mathrm{FE}_{\mathrm{Na}}$ and $\mathrm{UNa}$ /Uosm in postobstructive and contralateral control kidneys during course of a typical hydrated and hydropenic experiment.

TABLE I

Hydrated Experiments. Comparison of Postobstructive Kidney and Contralateral Control with Regard to Electrolyte Excretion Diluting Capacity and Sodium Supply to the Distal Nephron

\begin{tabular}{|c|c|c|c|c|c|c|c|c|c|c|c|c|c|c|c|}
\hline \multirow{2}{*}{\multicolumn{2}{|c|}{$\begin{array}{l}\text { Experi- } \\
\text { ments }\end{array}$}} & \multicolumn{2}{|c|}{ GFR } & \multicolumn{2}{|c|}{ UNaV } & \multicolumn{2}{|c|}{$F E_{\mathrm{Na}}$} & \multicolumn{2}{|c|}{$U_{K} V$} & \multicolumn{2}{|c|}{$\mathrm{CH}_{2} \mathrm{O}$} & \multicolumn{2}{|c|}{$\begin{array}{c}\mathrm{CH}_{2} \mathrm{O} / \mathrm{GFR} \\
\times 100\end{array}$} & \multicolumn{2}{|c|}{$\begin{array}{c}\mathrm{CH}_{1} \mathrm{O}+\mathrm{CNa} / \\
\mathrm{GFR} \times 100\end{array}$} \\
\hline & & CON & EXP & CON & EXP & CON & EXP & CON & EXP & CON & EXP & CON & EXP & CON & EXP \\
\hline & & \multicolumn{2}{|c|}{$m l / \min$} & \multicolumn{2}{|c|}{$\mu E q / \min$} & \multicolumn{2}{|c|}{$\%$} & \multicolumn{2}{|c|}{$\mu E q / \min$} & \multicolumn{2}{|c|}{$\mathrm{ml} / \mathrm{min}$} & \multicolumn{2}{|c|}{$\%$} & \multicolumn{2}{|c|}{$\%$} \\
\hline 1 & $\begin{array}{l}\text { A } \\
\text { B }\end{array}$ & $\begin{array}{l}47.9 \\
39.2\end{array}$ & $\begin{array}{l}26.3 \\
24.6\end{array}$ & $\begin{array}{r}7 \\
340\end{array}$ & $\begin{array}{l}121 \\
518\end{array}$ & $\begin{array}{l}0.1 \\
8.0\end{array}$ & $\begin{array}{r}3.5 \\
19.5\end{array}$ & $\begin{array}{l}11 \\
38\end{array}$ & $\begin{array}{l}8 \\
8\end{array}$ & $\begin{array}{l}4.27 \\
7.00\end{array}$ & $\begin{array}{l}1.73 \\
4.63\end{array}$ & $\begin{array}{r}8.9 \\
17.9\end{array}$ & $\begin{array}{r}6.6 \\
18.6\end{array}$ & $\begin{array}{r}5.9 \\
25.9\end{array}$ & $\begin{array}{l}10.1 \\
38.1\end{array}$ \\
\hline 2 & $\begin{array}{l}\text { A } \\
\text { B }\end{array}$ & $\begin{array}{l}57.6 \\
47.7\end{array}$ & $\begin{array}{l}39.6 \\
33.1\end{array}$ & $\begin{array}{r}24 \\
242\end{array}$ & $\begin{array}{l}102 \\
386\end{array}$ & $\begin{array}{l}0.3 \\
4.3\end{array}$ & $\begin{array}{l}1.9 \\
9.9\end{array}$ & $\begin{array}{l}24 \\
30\end{array}$ & $\begin{array}{l}14 \\
28\end{array}$ & $\begin{array}{l}4.39 \\
7.90\end{array}$ & $\begin{array}{l}4.41 \\
6.32\end{array}$ & $\begin{array}{r}7.6 \\
16.6\end{array}$ & $\begin{array}{l}11.1 \\
19.1\end{array}$ & $\begin{array}{r}7.9 \\
20.9\end{array}$ & $\begin{array}{l}13.0 \\
29.0\end{array}$ \\
\hline 3 & $\begin{array}{l}\text { A } \\
\text { B }\end{array}$ & $\begin{array}{l}26.9 \\
28.0\end{array}$ & $\begin{array}{l}12.9 \\
13.3\end{array}$ & $\begin{array}{r}46 \\
261\end{array}$ & $\begin{array}{r}73 \\
177\end{array}$ & $\begin{array}{l}1.4 \\
8.8\end{array}$ & $\begin{array}{r}4.6 \\
12.6\end{array}$ & $\begin{array}{l}23 \\
29\end{array}$ & $\begin{array}{l}10 \\
14\end{array}$ & $\begin{array}{l}2.06 \\
5.36\end{array}$ & $\begin{array}{l}0.74 \\
2.98\end{array}$ & $\begin{array}{r}7.7 \\
19.1\end{array}$ & $\begin{array}{c}5.74 \\
22.4\end{array}$ & $\begin{array}{r}9.1 \\
27.9\end{array}$ & $\begin{array}{l}10.3 \\
35.0\end{array}$ \\
\hline 4 & $\begin{array}{l}\text { A } \\
\text { B }\end{array}$ & $\begin{array}{l}23.8 \\
31.3\end{array}$ & $\begin{array}{l}18.9 \\
23.2\end{array}$ & $\begin{array}{l}10 \\
28\end{array}$ & $\begin{array}{l}144 \\
204\end{array}$ & $\begin{array}{l}0.3 \\
1.0\end{array}$ & $\begin{array}{l}5.9 \\
7.0\end{array}$ & $\begin{array}{l}22 \\
19\end{array}$ & $\begin{array}{l}21 \\
23\end{array}$ & $\begin{array}{r}-0.81 \\
3.84\end{array}$ & $\begin{array}{l}1.04 \\
3.78\end{array}$ & $\begin{array}{r}-3.3 \\
12.3\end{array}$ & $\begin{array}{r}5.5 \\
16.3\end{array}$ & $\begin{array}{r}-3.1 \\
13.3\end{array}$ & $\begin{array}{r}9.0 \\
23.3\end{array}$ \\
\hline 5 & $\begin{array}{l}\text { A } \\
\text { B }\end{array}$ & $\begin{array}{l}43.8 \\
37.0\end{array}$ & $\begin{array}{l}38.2 \\
33.9\end{array}$ & $\begin{array}{r}44 \\
186\end{array}$ & $\begin{array}{r}73 \\
405\end{array}$ & $\begin{array}{l}0.8 \\
4.2\end{array}$ & $\begin{array}{r}1.5 \\
10.8\end{array}$ & $\begin{array}{l}13 \\
37\end{array}$ & $\begin{array}{l}19 \\
52\end{array}$ & $\begin{array}{l}3.29 \\
5.42\end{array}$ & $\begin{array}{l}3.28 \\
4.95\end{array}$ & $\begin{array}{r}7.5 \\
13.7\end{array}$ & $\begin{array}{c}8.59 \\
14.6\end{array}$ & $\begin{array}{r}8.3 \\
18.2\end{array}$ & $\begin{array}{l}10.1 \\
25.4\end{array}$ \\
\hline 6 & $\begin{array}{l}\text { A } \\
\text { B }\end{array}$ & $\begin{array}{l}30.7 \\
31.5\end{array}$ & $\begin{array}{l}25.7 \\
23.9\end{array}$ & $\begin{array}{l}22 \\
68\end{array}$ & $\begin{array}{l}114 \\
202\end{array}$ & $\begin{array}{l}0.6 \\
1.8\end{array}$ & $\begin{array}{l}3.8 \\
7.1\end{array}$ & $\begin{array}{l}31 \\
24\end{array}$ & $\begin{array}{l}158 \\
151\end{array}$ & $\begin{array}{l}2.30 \\
3.90\end{array}$ & $\begin{array}{l}2.00 \\
3.40\end{array}$ & $\begin{array}{r}7.5 \\
12.5\end{array}$ & $\begin{array}{r}7.7 \\
14.2\end{array}$ & $\begin{array}{r}0.8 \\
14.4\end{array}$ & $\begin{array}{l}11.5 \\
21.3\end{array}$ \\
\hline Mean & $\begin{array}{l}\text { A } \\
\text { B }\end{array}$ & $\begin{array}{l}38.5 \\
35.8\end{array}$ & $\begin{array}{l}26.9 \\
25.3\end{array}$ & $\begin{array}{r}25 \\
189\end{array}$ & $\begin{array}{l}104 \\
315\end{array}$ & $\begin{array}{l}0.6 \\
4.7\end{array}$ & $\begin{array}{r}3.5 \\
11.1\end{array}$ & $\begin{array}{l}21 \\
29\end{array}$ & $\begin{array}{l}38 \\
46\end{array}$ & $\begin{array}{l}2.58 \\
5.57\end{array}$ & $\begin{array}{l}2.20 \\
4.34\end{array}$ & $\begin{array}{r}6.0 \\
15.3\end{array}$ & $\begin{array}{r}7.5 \\
17.5\end{array}$ & $\begin{array}{r}4.8 \\
20.1\end{array}$ & $\begin{array}{l}10.7 \\
28.7\end{array}$ \\
\hline$P$ value & $\begin{array}{l}\text { A } \\
\text { B }\end{array}$ & & & $\begin{array}{l}<0 \\
<0\end{array}$ & & & $\begin{array}{l}.01 \\
.01\end{array}$ & & $\begin{array}{l}\text { IS } \\
\text { IS }\end{array}$ & $\begin{array}{l}\mathbf{N} \\
\mathbf{N}\end{array}$ & & & & & \\
\hline
\end{tabular}

GFR, glomerular filtration rate (Ccreatinine or Cinulin); UNaV, urinary sodium excretion; FE urinary potassium excretion; $\mathrm{CH}_{2} \mathrm{O}$, free water clearance; $\mathrm{CH}_{2} \mathrm{O} / \mathrm{GFR} \times 100$, free water clearance as per cent of $\mathrm{GFR}$; $\mathrm{CH}$ of free water clearance and sodium clearance as fraction of GFR, A, value before hypotonic mannitol infusion; B, value during hypotonic mannitol infusion. CON, control kidney; EXP, experimental (postobstructive) kidney. 
TABLE II

Hydropenic Experiments. Comparison of Postobstructive Kidney and Contralateral Control with Regard to Electrolyte Excretion and Concentrating Capactty

\begin{tabular}{|c|c|c|c|c|c|c|c|c|c|c|c|}
\hline \multirow{2}{*}{\multicolumn{2}{|c|}{ Experiments }} & \multicolumn{2}{|c|}{ GFR } & \multicolumn{2}{|c|}{ UNaV } & \multicolumn{2}{|c|}{$\mathrm{FE}_{\mathrm{Na}}$} & \multicolumn{2}{|c|}{$\mathrm{UKV}_{\mathrm{K}}$} & \multicolumn{2}{|c|}{$T^{\mathrm{c}} \mathrm{H}_{2} \mathrm{O} \max$} \\
\hline & & CON & EXP & CON & EXP & CON & EXP & CON & EXP & CON & EXP \\
\hline & & \multicolumn{2}{|c|}{$m l / \min$} & \multicolumn{2}{|c|}{$\mu E q / \min$} & \multicolumn{2}{|c|}{$\%$} & \multicolumn{2}{|c|}{$\mu E q / \min$} & \multicolumn{2}{|c|}{$m l / m i n$} \\
\hline \multirow[t]{2}{*}{6} & A & 25.2 & 19.6 & 2 & 6 & 0.1 & 0.2 & 28 & 20 & $1.17(9)^{*}$ & $0.63(8)$ \\
\hline & B & 24.6 & 20.5 & 397 & 569 & 15.3 & 28.8 & 98 & 102 & & \\
\hline \multirow[t]{2}{*}{7} & A & 61.6 & 42.3 & 13 & 28 & 0.2 & 0.5 & 47 & 50 & $4.15(13)$ & 2.80 (12) \\
\hline & B & 48.5 & 39.4 & 317 & 614 & 5.2 & 12.5 & 70 & 134 & & \\
\hline \multirow[t]{2}{*}{8} & A & 47.2 & 29.4 & 8 & 43 & 0.1 & 1.0 & 33 & 19 & $3.70(8)$ & $1.55(6)$ \\
\hline & B & 39.3 & 35.2 & 388 & 704 & 7.7 & 15.6 & 71 & 84 & & \\
\hline \multirow[t]{2}{*}{9} & A & 46.4 & 35.2 & 27 & 30 & 0.4 & 0.6 & 39 & 16 & $2.54(9)$ & $1.18(8)$ \\
\hline & B & 39.4 & 33.8 & 322 & 362 & 6.2 & 8.2 & 165 & 116 & & \\
\hline \multirow[t]{2}{*}{10} & A & 51.4 & 37.8 & 23 & 42 & 0.3 & 0.8 & 35 & 42 & $3.60(14)$ & $2.40(14)$ \\
\hline & B & 51.0 & 47.3 & 234 & 567 & 3.6 & 7.8 & 83 & 133 & & \\
\hline \multirow[t]{2}{*}{11} & A & 38.7 & 13.5 & 53 & 29 & 1.0 & 1.5 & 20 & 8 & $1.49(9)$ & $0.04(5)$ \\
\hline & B & 39.9 & 27.6 & 414 & 448 & 9.8 & 15.3 & 50 & 31 & & \\
\hline \multirow[t]{2}{*}{12} & A & 38.4 & 15.1 & 35 & 48 & 0.7 & 2.3 & 16 & 14 & $2.71(12)$ & $0.15(8)$ \\
\hline & B & 45.7 & 24.9 & 465 & 535 & 9.0 & 19.0 & 70 & 77 & & \\
\hline \multirow[t]{2}{*}{13} & A & 55.7 & 9.1 & 82 & 55 & 1.0 & 4.2 & 38 & 6 & $3.87(10)$ & $0.14(7)$ \\
\hline & B & 37.9 & 28.9 & 343 & 1106 & 7.3 & 30.9 & 61 & 113 & & \\
\hline \multirow[t]{2}{*}{14} & A & 67.6 & 24.6 & 22 & 15 & 0.2 & 0.4 & 64 & 16 & $2.60(10)$ & 1.37 (10) \\
\hline & B & 61.0 & 43.6 & 14 & 102 & 0.2 & 1.8 & 27 & 24 & & \\
\hline \multirow[t]{2}{*}{15} & A & 62.1 & 14.6 & 104 & 31 & 1.2 & 1.5 & 50 & 13 & $3.30(9)$ & $0.35(9)$ \\
\hline & B & 45.8 & 29.0 & 360 & 526 & 7.6 & 17.6 & 87 & 91 & & \\
\hline \multirow[t]{2}{*}{16} & A & 57.7 & 17.6 & 13 & 15 & 0.2 & 0.6 & 24 & 9 & $4.30(13)$ & $1.32(10)$ \\
\hline & B & 53.8 & 41.1 & 187 & 672 & 2.7 & 12.9 & 58 & 127 & & \\
\hline \multirow[t]{2}{*}{ Mean } & A & 45.6 & 23.5 & 35 & 31 & 0.5 & 1.2 & 36 & 19 & 3.03 & 1.08 \\
\hline & B & 44.3 & 33.8 & 313 & 564 & 6.8 & 15.5 & 77 & 94 & & \\
\hline \multirow[t]{2}{*}{$P$ value } & A & \multirow{2}{*}{\multicolumn{2}{|c|}{$\begin{array}{l}<0.001 \\
<0.001\end{array}$}} & \multirow{2}{*}{\multicolumn{2}{|c|}{$\begin{array}{l}<0.001 \\
<0.05\end{array}$}} & \multirow{2}{*}{\multicolumn{2}{|c|}{$\begin{array}{l}<0.05 \\
<0.001\end{array}$}} & \multirow{2}{*}{\multicolumn{2}{|c|}{$\begin{array}{c}<0.01 \\
\mathrm{NS}\end{array}$}} & $<0$ & \\
\hline & B & & & & & & & & & & \\
\hline
\end{tabular}

$\mathrm{T}^{\circ} \mathrm{H}_{2} \mathrm{O}$ max = maximum solute free water reabsorption; $\mathrm{A}=$ value before hypertonic mannitol or glucose infusion; $\mathrm{B}=$ value during hypertonic mannitol or glucose infusion; for other abbreviations see Table $\mathrm{I}$.

* Numbers in parentheses represent the collection period in which the value was obtained.

perimental kidney there was a mild dilatation of the collecting tubules particularly in the outer zone of the medulla. A number of tubules in the medulla, particularly loops of Henle, contained hyaline casts. Several similar casts were also present in the control kidney.

Electron microscopy of tubular cells revealed nonspecific changes of vacuoles and lipid droplets in both kidneys without any apparent distinction between the control and experimental kidneys.

Glomerular filtration rate (GFR). The mean GFR for the postobstructive (experimental) kidney (POK) and contralateral control was determined for each kidney.
The GFR in the postobstructive kidney was decreased in all studies, reductions ranging from 13 to $65 \%$ of the control kidney. In most studies the GFR tended to remain stable throughout the experiment; in others there were early progressive increments in GFR in the postobstructive kidney which stabilized after five to six collection periods. Changes in renal plasma flow (RPF) paralleled those of GFR.

Sodium excretion. Despite the variable reduction in GFR, there was generally an increase in absolute sodium excretion in the experimental kidney before infusion of nonreabsorbable solute (Fig. 1, Tables I-IV). During 
TABLE III

Representative

\begin{tabular}{|c|c|c|c|c|c|c|c|c|c|}
\hline \multirow[b]{2}{*}{ Period } & \multirow[b]{2}{*}{ Time } & \multicolumn{2}{|c|}{$\mathbf{v}$} & \multicolumn{2}{|c|}{ CCREAT } & \multicolumn{2}{|c|}{ UNAV } & \multicolumn{2}{|c|}{$\begin{array}{l}\text { UNAV/FN } \\
\quad \times 100\end{array}$} \\
\hline & & CON & EXP & CON & EXP & CON & EXP & CON & E \\
\hline & $\min$ & \multicolumn{2}{|c|}{$\mathrm{ml} / \mathrm{min}$} & \multicolumn{2}{|c|}{$\mathrm{ml} / \mathrm{min}$} & \multicolumn{2}{|c|}{$\mu E q / \min$} & \multicolumn{2}{|c|}{$\%$} \\
\hline & $\begin{array}{r}0 \\
20 \\
70\end{array}$ & \multicolumn{8}{|c|}{$\begin{array}{l}\text { Primes administered; constant infusion started: creatinine } 20 \mathrm{mg} / \mathrm{min} \text {, } \\
2.5 \% \mathrm{D} / \mathrm{W} \text { in } 0.2 \% \mathrm{~N}_{\mathrm{A}} \mathrm{CL}_{\mathrm{L}} \mathrm{I}-\mathrm{V} \text { at } 10 \mathrm{ml} / \mathrm{min}\end{array}$} \\
\hline 1 & $130-140$ & 6.60 & 6.45 & 57.6 & 39.6 & 24 & 102 & 0.3 & 1.9 \\
\hline & & \multicolumn{8}{|c|}{$2.5 \%$ mannitol in $0.2 \% \mathrm{~N}_{\mathrm{A}} \mathrm{CL}_{\mathrm{L}}$ administered $\mathrm{I}-\mathrm{V}$ at gradually increasing } \\
\hline 2 & 149-159 & 9.27 & 8.00 & 60.6 & 40.7 & 50 & 134 & 0.6 & 2.5 \\
\hline 3 & $179-189$ & 10.2 & 9.55 & 55.9 & 40.5 & 101 & 221 & 1.4 & 4.1 \\
\hline 4 & $223-243$ & 12.2 & 10.2 & 45.3 & 32.5 & 116 & 198 & 2.0 & 4.9 \\
\hline 5 & $253-263$ & 13.8 & 11.1 & 42.0 & 30.0 & 88 & 192 & 1.7 & 5.1 \\
\hline 6 & $273-283$ & 15.9 & 13.0 & 43.6 & 32.4 & 130 & 280 & 2.5 & 7.0 \\
\hline 7 & $283-293$ & 16.9 & 14.5 & 47.9 & 33.4 & 184 & 323 & 3.1 & 7.9 \\
\hline 8 & $303-313$ & 18.6 & 15.7 & 47.7 & 33.1 & 242 & 386 & 4.3 & 9.9 \\
\hline
\end{tabular}

$\mathrm{V}$, urine flow rate, CCREAT, creatinine clearance (GRF), $\mathrm{C}_{\mathrm{os}}$, solute clearance. For other abbreviations see Tables I and II.

mannitol or glucose diuresis, $\mathrm{UNaV}$ increased progressively in both kidneys and remained greater in the experimental kidney (mean hydropenic, 1.8 times control; mean hydrated, 1.7 times control) even at high rates of solute excretion (Fig. 1, Tables I-IV).

There was a consistent increase in the fraction of the filtered load of sodium excreted by the experimental kidney before the infusion of nonreabsorbable solute (mean hydrated, 6 times control; mean hydropenic, 2.4 times control) (Figs. 1 and 4 ; Tables I-IV, VI). As the diuresis progressed fractional sodium excretion in the experimental kidney rose at a more rapid rate than the control and showed a decreased tendency to level off at high fractional excretions (Figs. 1 and 4 ) mean hydrated 2.4 times control; mean hydropenic, 2.3 times control).

In addition, urinary concentration of sodium, UNa, was higher in the experimental kidney. Moreover, the fraction $\mathrm{UNa} / \mathrm{Uosm}^{8}$ remained higher in the experimental kidney during simultaneous collection periods (Fig. 1, Tables III and IV).

Potassium excretion. In the hydrated studies, mean potassium excretion was higher in the experimental kidney before and during mannitol as well as during mannitol in the hydropenic studies (Tables I and II). Although mean $\mathrm{K}$ excretion was lower before mannitol in the hydropenic studies (Table II) this may be related to the fact that absolute sodium excretion was also lower,

\footnotetext{
${ }^{3}$ In order to correct for changes in sodium concentration consequent upon alterations in water reabsorption alone, $\mathrm{UNa}$ was factored by total urinary solute concentration, Uosm. Since plasma sodium is identical in both kidneys, increases in $\mathrm{UNa}$ /Uosm represent decreases in net transtubular-sodium concentration gradient (10).
}

since decreases in GFR were maximal at this time. Nevertheless in several individual experiments, both hydrated and hydropenic, $\mathrm{K}$ excretion was lower in the POK than in the control kidney although these were generally instances in which the POK showed only a small increase in absolute sodium excretion when compared to the control kidney.

Diluting capacity. During hypotonic mannitol loading, $\mathrm{CH}_{2} \mathrm{O}$ increased progressively in both kidneys, but was lower on the experimental side in which GFR was decreased (Fig. 2, Tables I and III). However, $\mathrm{CH}_{2} \mathrm{O}$ may be adjusted for differences in filtration rate by the expression $\mathrm{CH}_{2} \mathrm{O} / \mathrm{GFR}$ times 100 . This parameter, denoting the fraction of GFR which is excreted as solute free water, was higher in the experimental kidney in all studies after mannitol (Fig. 2, Tables I and III). Where the reduction in solute clearance ${ }^{5}$ was not excessive, this

\footnotetext{
' In some instances $\mathrm{K}$ excretion may be limited because the lower GFR in the POK may be due to some extent to nonfunctioning nephrons, as will be inferred later in the glucose $\mathrm{Tm}$ studies. In this situation it is apparent that at a time when $\mathrm{UNaV}$ is similar in both kidneys the $\mathrm{K}$ secretory sites of the functioning nephrons in the POK are subjected to a greater sodium supply per nephron than the control kidney. Since increments in $\mathrm{UNaV}$ may be associated with less than proportional increases in UKV, the POK would thereby be expected to have a somewhat lower $\mathrm{UKV}$ at similar levels of UNaV.

${ }^{5}$ Despite the consistent reduction in GFR and filtered solute load in the experimental xidney, levels of solute excretion were generally similar during simultaneous collection periods. Differences in back diffusion of solute free water as a result of differences in solute excretion (11) are thereby minimized.
} 
Hydrated Experiment

\begin{tabular}{|c|c|c|c|c|c|c|c|c|c|}
\hline \multicolumn{2}{|c|}{$\begin{array}{l}\text { UNA/Uosm } \\
\times 100\end{array}$} & \multicolumn{2}{|c|}{ Cosm } & \multicolumn{2}{|c|}{$\mathrm{CH}_{2} \mathrm{O}$} & \multicolumn{2}{|c|}{$\begin{array}{c}\mathrm{CH}_{2} \mathrm{O} / \mathrm{GFR} \\
\times 100\end{array}$} & \multicolumn{2}{|c|}{$\begin{array}{c}\mathrm{CH}_{2} \mathrm{O}+\mathrm{CN}_{\mathrm{A}} \\
\mathrm{GFR} \times 100\end{array}$} \\
\hline CON & EXP & CON & EXP & CON & EXP & CON & EXP & CON & EXP \\
\hline
\end{tabular}

PAH $4 \mathrm{mg} / \mathrm{min}$. Left ureter catheterized.

\begin{tabular}{llcccccccc}
$\begin{array}{l}3.56 \\
\text { rates }\end{array}$ & 16.6 & 2.21 & 2.04 & 4.39 & 4.41 & 7.62 & 11.1 & 7.9 & 13.0 \\
6.0 & 17.9 & 2.80 & 2.52 & 6.47 & 5.48 & 10.7 & 13.5 & 11.3 & 16.0 \\
7.92 & 17.8 & 4.22 & 4.11 & 5.98 & 5.44 & 10.7 & 13.4 & 12.1 & 17.5 \\
6.33 & 12.4 & 6.22 & 5.45 & 5.98 & 4.75 & 13.2 & 14.6 & 15.2 & 19.5 \\
4.24 & 10.7 & 7.09 & 6.08 & 6.71 & 5.02 & 16.0 & 16.7 & 17.7 & 20.0 \\
6.68 & 12.7 & 8.64 & 7.32 & 7.26 & 5.68 & 16.7 & 17.5 & 19.2 & 24.5 \\
6.65 & 13.0 & 9.30 & 8.32 & 7.60 & 6.18 & 15.9 & 18.5 & 19.0 & 26.4 \\
7.55 & 13.8 & 10.7 & 9.38 & 7.9 & 6.32 & 16.6 & 19.1 & 20.9 & 29.0 \\
\hline
\end{tabular}

parameter was also higher in the experimental kidney before mannitol (Tables I and III).

To determine whether there was any consistent alteration in the fraction of the filtered sodium load reaching distal water-freeing sites, an index of fractional distal sodium supply, $\mathrm{CH}_{2} \mathrm{O}+\mathrm{CNa} / \mathrm{GFR}$ times 100 was utilized (10). In all studies, this index was consistently higher in the experimental kidney (Fig. 2, Tables I and III).

Concentrating capacity. During the infusion of mannitol $\mathrm{T}^{\mathrm{c}} \mathrm{H}_{2} \mathrm{O}$ generally increased bilaterally. The rate of increase in $\mathrm{T}^{\mathrm{c}} \mathrm{H}_{2} \mathrm{O}$ was somewhat lower in the experimental kidney and the maximal level of $\mathrm{T}^{\mathrm{c}} \mathrm{H}_{2} \mathrm{O}$ was attained earlier in time and at a greater fractional so-

TABLE IV

Representative Hydropenic Experiment

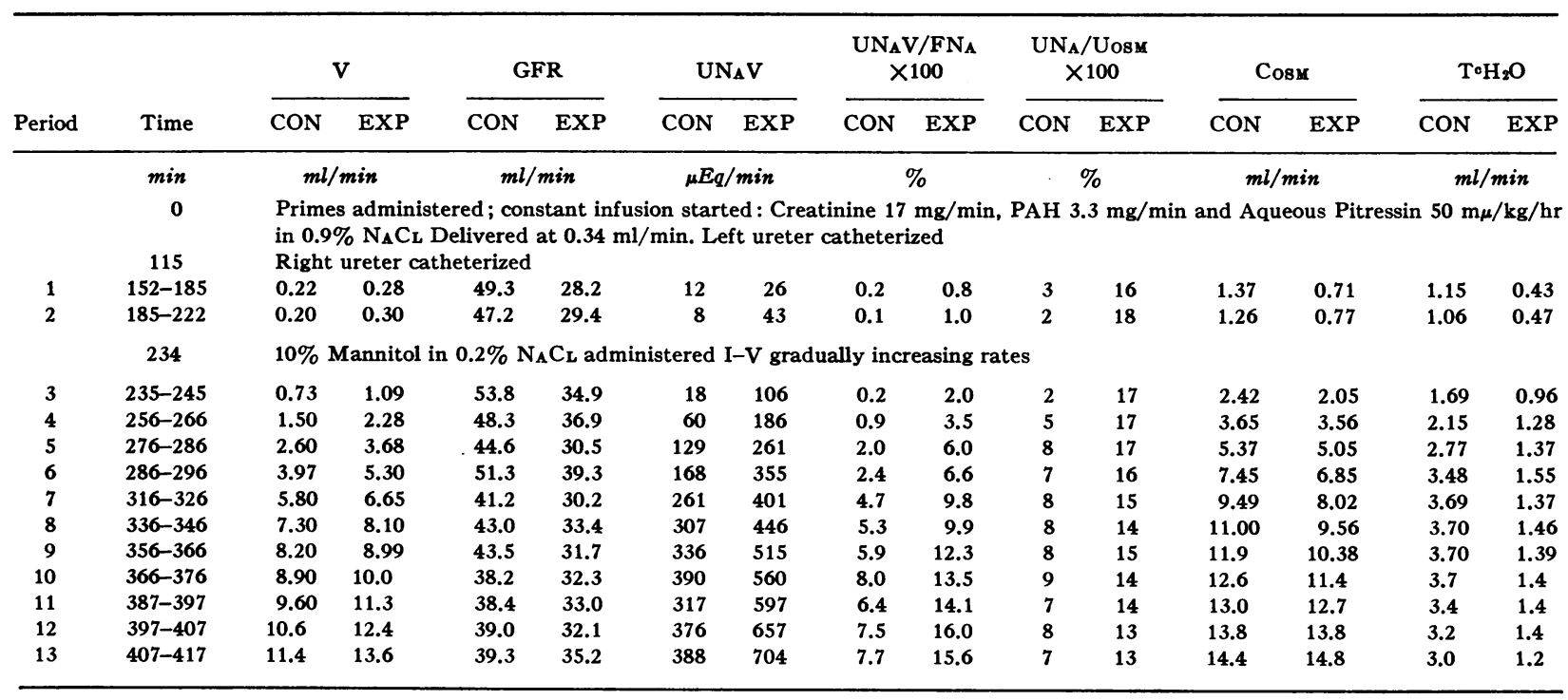

For abbreviations see Tables I-III. 

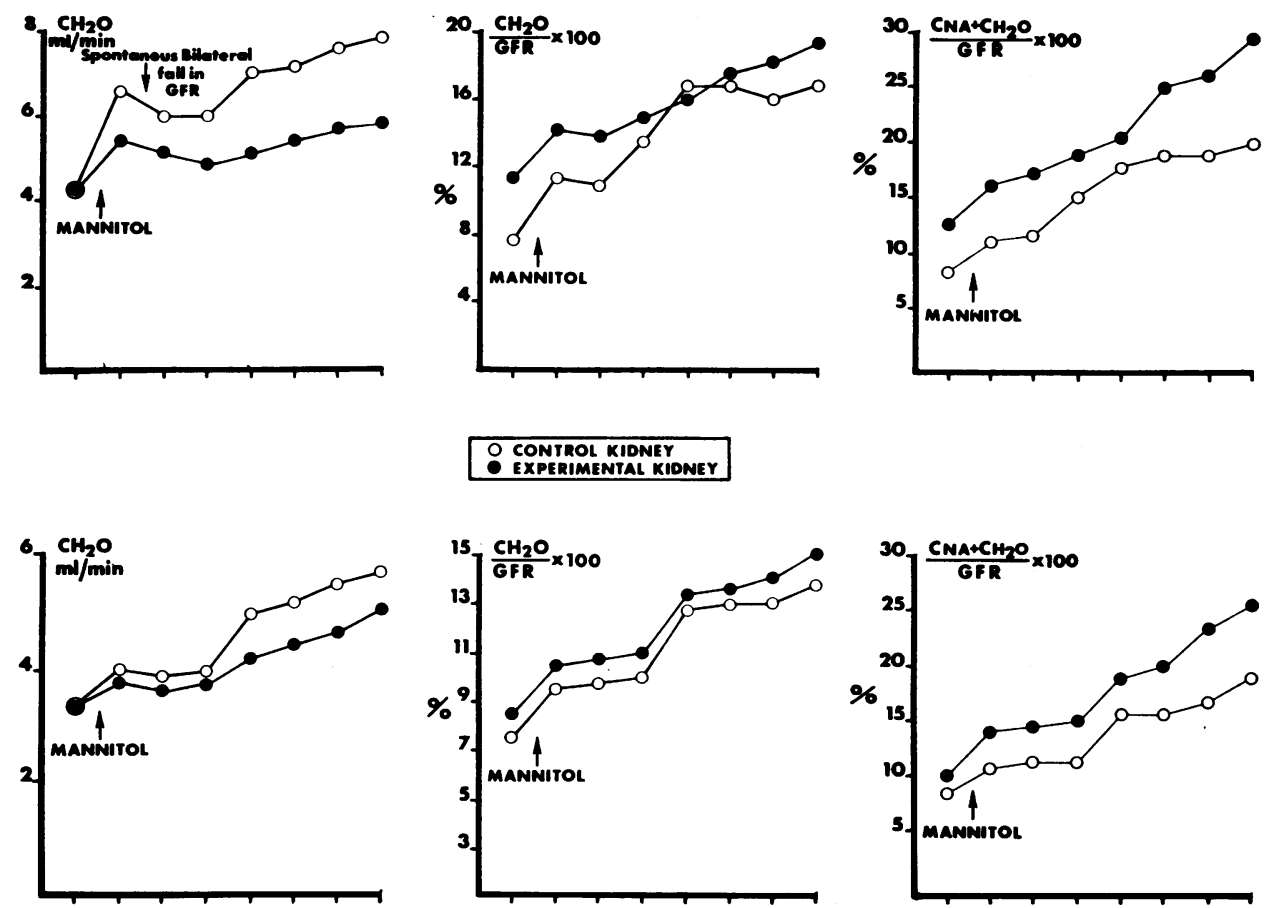

Figure $2 \mathrm{CH}_{2} \mathrm{O}, \mathrm{CH}_{2} \mathrm{O} / \mathrm{GFR}$, and $\mathrm{CNa}+\mathrm{CH}_{2} \mathrm{O} / \mathrm{GFR}$ in postobstructive kidney and contralateral control in two hydrated experiments.

dium excretion when compared with the control kidney (Fig. 3, Tables II, IV, and VI). There was a stable plateau in both kidneys followed by a gradual decrease in $\mathrm{T}^{\mathrm{e}} \mathrm{H}_{2} \mathrm{O}$ at high rates of solute excretion (Fig. 3, Table IV).

To adjust for decreases in GFR in the experimental kidney $\mathrm{T}^{\mathrm{c}} \mathrm{H}_{2} \mathrm{O} / \mathrm{GFR}$ was calculated in consecutive collection periods for each kidney. The quantitative relationship between the two curves remained similar to the original $\mathrm{T}^{\mathrm{e}} \mathrm{H}_{2} \mathrm{O}$ curves from which they were derived (Fig. 3).

In several studies, the greatest reduction in GFR occurred in the early periods after the release of obstruction. The GFR in the experimental kidney gradually increased and then stabilized, generally at a value greater than $50 \%$ of the control. In these experiments, absolute sodium excretion was sometimes lower in the experimental kidney, but fractional sodium excretion remained higher throughout each study (Fig. 4, Table II, experiments 11, 13, 15). Early in these studies, unusually low levels of $\mathrm{T}^{\mathrm{c}} \mathrm{H}_{2} \mathrm{O}$ (less than $\frac{1}{2} \mathrm{ml}$ ) were reached in the experimental kidney and there was a rapid fall in urinary osmolality to levels below the level of plasma resulting in the formation of negative $\mathrm{T}^{\mathrm{c}} \mathrm{H}_{2} \mathrm{O}$ or $\mathrm{CH}_{2} \mathrm{O}$ (Fig. 4). As fractional sodium excretion increased, $\mathrm{CH}_{2} \mathrm{O}$ also progressively increased reaching levels of $2-3 \mathrm{ml}$ per min (Fig. 4). The characteristics of the $\mathrm{T}^{\mathrm{e}} \mathrm{H}_{2} \mathrm{O}$ curve of the control kidney were similar to those in experiments with modest GFR reduction.

Glucose Tm. In six of the hydropenic studies, the Tm glucose for each kidney was determined. This parameter was reduced in the experimental kidney in each study, but to a lesser degree than the reduction in GFR; a mean reduction in $\mathrm{Tm}$ of $35 \%$ compared with a mean reduction in GFR of $49 \%$. It was found, therefore, that GFR/Tm glucose was consistently lower in the experimental than in the control kidney (Table V).

In three glucose-titration studies, plasma glucose was slowly raised to determine the level at which glycosuria first occurred. In two experiments initial glycosuria was noted in the control kidney at a lower plasma glucose level than in the experimental kidney; in the third glycosurià was detected simultaneously. A representative glucose titration experiment is presented in Table VI. The plasma glucose level was gradually raised from 90 to $732 \mathrm{mg}$ per $100 \mathrm{ml}$. At a plasma glucose level of 221 $\mathrm{mg}$ per $100 \mathrm{ml}$ glycosuria was present on the control side, but not on the experimental side. During the course of the experiment, $\mathrm{T}^{\mathrm{c}} \mathrm{H}_{2} \mathrm{O}$ is greatly decreased in the experimental kidney while fractional sodium excretion is higher.

In three studies in which a glucose load was administered in order to reach $\mathrm{Tm}$ levels without titration, blood glucose levels of at least $400 \mathrm{mg}$ per $100 \mathrm{ml}$ were 

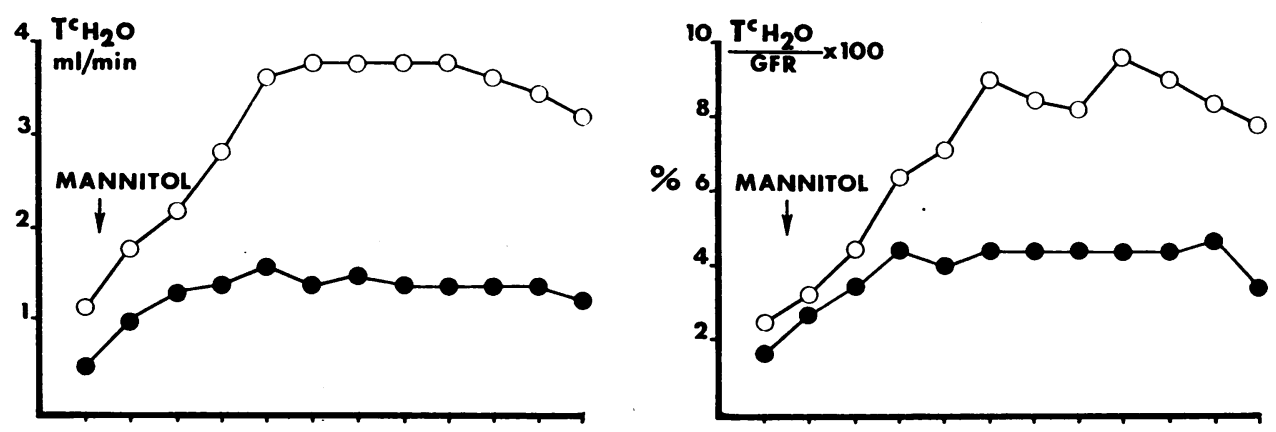

O CONTROL KIDNEY

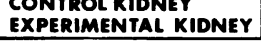
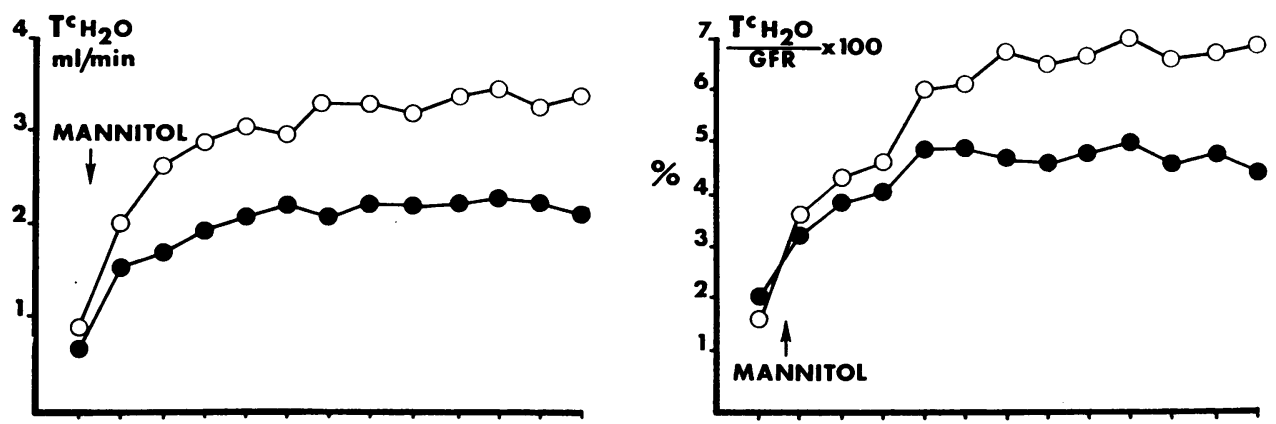

Figure $3 \mathrm{~T}^{\mathrm{c}} \mathrm{H}_{2} \mathrm{O}$ and $\mathrm{T}^{\mathrm{c}} \mathrm{H}_{2} \mathrm{O} / \mathrm{GFR}$ times 100 in postobstructive kidney and contralateral control in two hydropenic experiments.
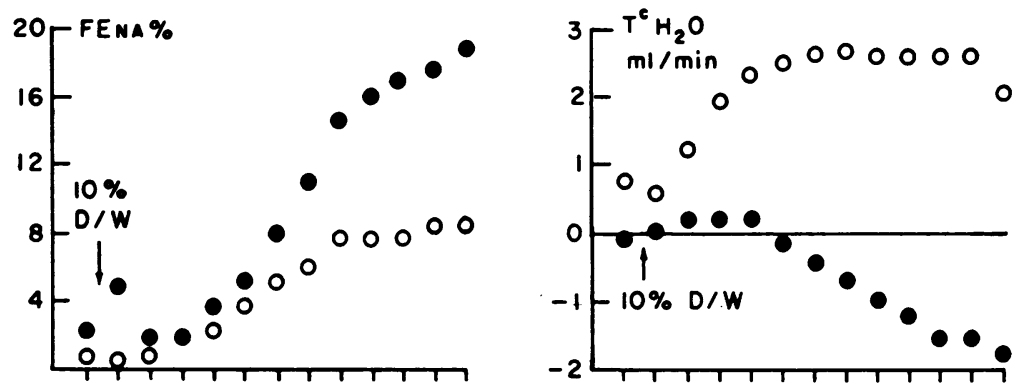

- CONTROL KIDNEY

- EXPERIMENTAL KIDNEY

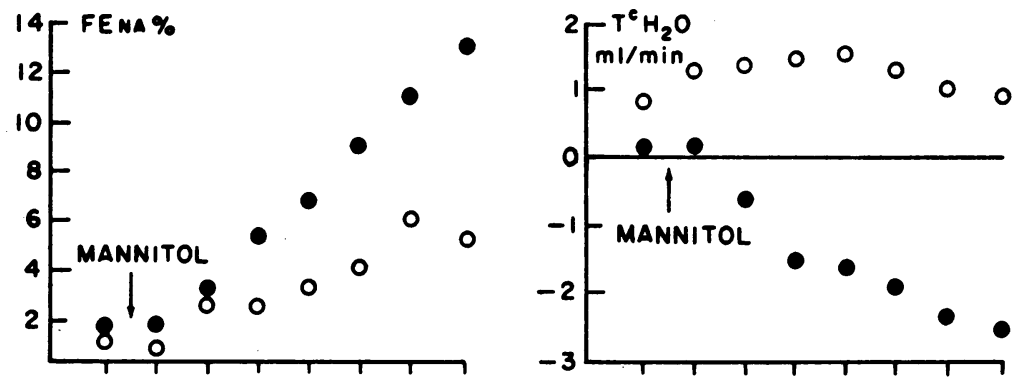

Figure $4 \mathrm{FE}_{\mathrm{Na}}$ and $\mathrm{T}^{\mathrm{c}} \mathrm{H}_{2} \mathrm{O}$ falling to $\mathrm{CH}_{2} \mathrm{O}$ in postobstructive kidney and contralateral control in two hydropenic experiments. 
TABLE V

Glomerular Filtration Rate, $T_{M}$ Glucose, and GFR/T $T_{M}$ Glucose in Postobstructive Kidney and Contralateral Control

\begin{tabular}{|c|c|c|c|c|c|c|c|}
\hline \multirow{2}{*}{$\begin{array}{c}\text { Experi- } \\
\text { ment }\end{array}$} & \multirow[b]{2}{*}{ Weight } & \multicolumn{2}{|c|}{ GFR } & \multicolumn{2}{|c|}{ TM Glucose } & \multicolumn{2}{|c|}{$\underset{\text { Glucose }}{\text { GFR/T }}$} \\
\hline & & CON & EXP & CON & EXP & CON & EX \\
\hline & $\mathrm{kg}$ & \multicolumn{2}{|c|}{$m l / \min$} & \multicolumn{2}{|c|}{$m g / \min$} & & \\
\hline 11 & 19 & 40.8 & 24.5 & 105 & 94 & 0.39 & 0.26 \\
\hline 12 & 23 & 50.6 & 20.8 & 153 & 81 & 0.33 & 0.26 \\
\hline 13 & 20 & 59.8 & 22.9 & 198 & 100 & 0.30 & 0.23 \\
\hline 14 & 22 & 63.1 & 41.8 & 180 & 127 & 0.35 & 0.33 \\
\hline 15 & 22 & 71.0 & 32.6 & 173 & 103 & 0.41 & 0.32 \\
\hline 16 & 19 & 63.7 & 35.5 & 170 & 115 & 0.38 & 0.31 \\
\hline Mean & & 58.2 & 29.7 & 163 & 103.3 & 0.36 & 0.28 \\
\hline$P$ & & \multicolumn{2}{|c|}{0.001} & \multicolumn{2}{|c|}{0.01} & \multicolumn{2}{|c|}{0.01} \\
\hline
\end{tabular}

CON, control kidney; EXP, experimental kidney; $T_{M}$ glucose, maximal reabsorptive rate of glucose.

noted early in the experiment at a time when there was marked depression of the GFR. However, by the time Tm glucose levels were reached GFR was stable.

\section{DISCUSSION}

In all studies, the postobstructive kidney showed a diminished capacity to conserve sodium with failure to establish a transtubular sodium concentration gradient comparable with that noted in the control kidney. This was reflected in a consistent increase in the fraction of the filtered sodium load excreted by the experimental kidney, frequent absolute increases in sodium despite the fall in GFR, and increased UNa/Uosm (Fig. 1, Tables I-IV and VI).

Some insight into the predominant tubular locus of decreased sodium reabsorption may be gained by the use of $\mathrm{CH}_{2} \mathrm{O}$ and $\mathrm{T}^{\mathrm{c}} \mathrm{H}_{2} \mathrm{O}$ formation. Previous reports from this and other laboratories have utilized these param- eters, in hydrated and hydropenic states, respectively, to evaluate the effects of diverse stimuli on sodium reabsorption at separate nephron sites. It is now generally accepted that in the hydrated state water is freed by the absorption of sodium from a water impermeable tubular segment primarily at, and probably also distal to, the ascending limb of Henle's loop. An agent which inhibits proximal sodium reabsorption would then increase distal sodium supply and $\mathrm{CH}_{2} \mathrm{O}$ would rise, in large part because of the increase in sodium reabsorption at and beyond the ascending limb. Inhibition at the loop of Henle or more distal sites would either decrease $\mathrm{CH}_{2} \mathrm{O}(13,14)$ or leave it unchanged (15). In these terms $\mathrm{CH}_{2} \mathrm{O}$ formation may be used as an indirect index of ascending limb sodium transport (15), and the sum of $\mathrm{CH}_{2} \mathrm{O}$ plus $\mathrm{CNa}$ a rough estimate of distal sodium supply (10).

The uniform increases in $\mathrm{CH}_{2} \mathrm{O}+\mathrm{CNa} / \mathrm{GFR}$ in the POK suggests that there is enhanced fractional sodium supply to the distal nephron. Although $\mathrm{CH}_{2} \mathrm{O} / \mathrm{GFR}$ was not consistently elevated before mannitol when GFR tended to be lowest, this parameter was also increased in the POK during mannitol administration when GFR was stable. This further suggests that the enhanced fractional sodium supply resulted in increased sodium transport in the distal, water impermeable nephron. It therefore appears that while the proximal nephron reabsorbs less sodium after obstruction, the distal nephron largely retains its capacity for sodium transport.

\footnotetext{
${ }^{6}$ It has been argued that the increase in free water might also result from a diminished rate of back-diffusion of collecting duct water as urine flow rate increases and the $\mathrm{Na}$ concentration in late distal tubular fluid rises (11). Nevertheless it is assumed that at high flow rates back-diffusion in the hydrated state is probably meager and this factor is currently assigned minor importance in the total rise in free water produced by increasing the distal supply of absorbable solute (12).
}

TABLE VI

Representative Glucose Titration Experiment

\begin{tabular}{|c|c|c|c|c|c|c|c|c|c|c|c|c|c|c|c|c|}
\hline \multirow[b]{2}{*}{ Period } & \multirow[b]{2}{*}{ Time } & \multirow{2}{*}{$\begin{array}{l}\text { Plasma } \\
\text { glucose }\end{array}$} & \multicolumn{2}{|c|}{ GFR } & \multicolumn{2}{|c|}{$\begin{array}{l}\text { Glucose } \\
\text { excretion }\end{array}$} & \multicolumn{2}{|c|}{$\begin{array}{c}\mathrm{T} \\
\text { glucose }\end{array}$} & \multicolumn{2}{|c|}{$\begin{array}{l}\mathrm{T} / \mathrm{T}_{\mathrm{M}} \\
\text { glucose }\end{array}$} & \multicolumn{2}{|c|}{$\begin{array}{l}\text { Load/TM } \\
\text { glucose }\end{array}$} & \multicolumn{2}{|c|}{$\begin{array}{c}\mathrm{UN}_{\mathbf{A}} / \mathrm{V} \\
\mathrm{FN}_{\mathbf{A}} \times 100\end{array}$} & \multicolumn{2}{|c|}{$\mathrm{T} \cdot \mathrm{H}_{2} \mathrm{O}$} \\
\hline & & & CON & EXP & $\mathrm{CON}$ & EXP & CON & ESP & $\mathrm{CON}$ & EXP & $\mathrm{CON}$ & EXP & CON & EXP & $\mathrm{CON}$ & EXP \\
\hline & $\min$ & $g m \%$ & \multicolumn{2}{|c|}{$\operatorname{ml} / \min$} & \multicolumn{2}{|c|}{$m g / \min$} & \multicolumn{2}{|c|}{$m g / m i n$} & & & \multicolumn{2}{|c|}{$m g / \min$} & \multicolumn{2}{|c|}{$\%$} & \multicolumn{2}{|c|}{$m l / \min$} \\
\hline & 60 & \multicolumn{15}{|c|}{$\begin{array}{l}\text { Primes administered. Constant infusion st } \\
\text { livered at } 0.34 \mathrm{ml} / \mathrm{min} \text {. Left ureter cathet } \\
\text { Right ureter catheterized }\end{array}$} \\
\hline 1 & $\begin{array}{c}119-135 \\
137\end{array}$ & $\begin{array}{l}90 \\
7.5 \% \text { D }\end{array}$ & \multicolumn{13}{|c|}{$7.5 \% \mathrm{D} / \mathrm{W} \mathrm{I}-\mathrm{V}$ started } & -0.03 \\
\hline 2 & $170-200$ & 122 & 64.0 & 17.1 & $\mathbf{0}$ & $\mathbf{0}$ & 78 & 20.9 & 0.45 & 0.20 & 0.45 & 0.20 & 0.7 & 1.0 & 1.00 & 0.09 \\
\hline 3 & $234-268$ & 180 & 69.4 & 20.6 & 0 & $\mathbf{0}$ & 125 & 37.1 & 0.72 & 0.36 & 0.72 & 0.36 & 1.0 & 1.1 & 1.18 & 0.15 \\
\hline 4 & $268-312$ & 221 & 72.5 & 27.6 & 7.3 & 0 & 153 & 61.0 & 0.88 & 0.59 & 0.93 & 0.59 & 1.3 & 1.2 & 1.48 & 0.20 \\
\hline 5 & $327-351$ & 306 & 72.2 & 33.8 & 55.0 & 2.8 & 166 & 100.0 & 0.96 & 0.97 & 1.28 & 1.00 & 2.1 & 1.6 & 2.00 & 0.27 \\
\hline 6 & $351-399$ & 360 & 75.1 & 32.2 & 96.0 & 11.0 & 174 & 105.0 & 1.01 & 1.02 & 1.56 & 1.13 & 1.7 & 2.0 & 2.38 & 0.31 \\
\hline 7 & 404 & \multicolumn{15}{|c|}{$12.5 \% \mathrm{D} / \mathrm{W} \mathrm{I}-\mathrm{V}$ started } \\
\hline 7 & $420-438$ & 588 & 69.7 & 33.4 & 240.0 & 88.0 & 170 & 108.0 & 0.98 & 1.05 & 2.38 & 1.82 & 2.3 & 4.6 & 3.11 & 0.23 \\
\hline 8 & $460-470$ & 732 & 63.3 & 31.0 & 326.0 & 129.0 & 177 & 98.0 & 1.02 & 0.95 & 2.90 & 2.20 & 2.5 & 4.9 & 3.08 & 0.19 \\
\hline
\end{tabular}


The results of the hydropenic studies are consistent with this conclusion. Although $\mathrm{T}^{c} \mathrm{H}_{2} \mathrm{O}$ has also been used as an index of ascending limb sodium supply and transport (16), the demonstration by direct (17) and indirect $(11,18-20)$ means that hypotonic distal tubular fluid fails to reattain isotonicity may spuriously lower the $\mathrm{T}^{\mathrm{c}} \mathrm{H}_{2} \mathrm{O}$ value. Therefore as a solute diuresis increases distal sodium reabsorption, and frees more water, the calculated $\mathrm{T}^{\mathrm{c}} \mathrm{H}_{2} \mathrm{O}$ value may plateau or fall despite increases in ascending limb sodium transport and collecting duct water reabsorption. When the quantity of distal water freed exceeds a critical level, collecting duct reabsorption may fail to return the fluid to isotonicity and $\mathrm{T}^{\mathrm{c}} \mathrm{H}_{2} \mathrm{O}$ will fall to negativity (i.e. to $\mathrm{CH}_{2} \mathrm{O}$ ). In hydropenic dog, a sharp increase in distal sodium supply and reabsorption may thus provoke a prompt fall in measured $\mathrm{T}^{\mathrm{c}} \mathrm{H}_{2} \mathrm{O}$. The moderately lower $\mathrm{T}^{\mathrm{c}} \mathrm{H}_{2} \mathrm{O}$ and $\mathrm{T}^{\mathrm{c}} \mathrm{H}_{2} \mathrm{O} / \mathrm{GFR}$ in the postobstructive kidney in most experiments (Fig. 3) and the rapid fall in $\mathrm{T}^{\mathrm{e}} \mathrm{H}_{2} \mathrm{O}$ to increasing levels of $\mathrm{CH}_{2} \mathrm{O}$ in other experiments (Fig. 4) are therefore both consistent with a marked increase in sodium supply to and transport by the distal nephron indicating reduced absorption by the proximal tubule.

The results presented in these studies are in contrast with those reported earlier from our laboratory using similar methods to evaluate the effects of a unilateral fall in GFR induced by acute partial constriction of one renal artery (10). After a Blalock clamp was applied to the right renal artery, mannitol was infused at increasing rates in either hydrated or hydropenic dogs as in the present protocol.

In the previously published studies, the fall in GFR after clamping resulted in decreased absolute and fractional sodium excretion. Enhanced sodium reabsorption in the proximal nephron with decreased sodium delivery to distal sites was suggested by decreases in $\mathrm{CH}_{2} \mathrm{O}, \mathrm{CH}_{2} \mathrm{O}$ / $\mathrm{GFR}$, and in $\mathrm{CNa}+\mathrm{CH}_{2} \mathrm{O} / \mathrm{GFR}$ as well as lower $\mathrm{UNa} /$ Uosm. Several differences between the constricted $\mathrm{T}^{\mathrm{c}} \mathrm{H}_{2} \mathrm{O}$ curves and the present postobstructive $\mathrm{T}^{\mathrm{c}} \mathrm{H}_{2} \mathrm{O}$ curves were apparent. In the constricted kidney there was a slower continuing rise in $\mathrm{T}^{\mathbf{c}} \mathrm{H}_{2} \mathrm{O}$ with a delayed plateau, while $\mathrm{T}^{\mathrm{c}} \mathrm{H}_{2} \mathrm{O}$ in the control kidney was simultaneously falling to negativity, i.e., to $\mathrm{CH}_{2} \mathrm{O}$ (10). This indicated a relatively slower increase in distal sodium supply in the constricted kidney compared to the contralateral control. In the POK, as already noted, there was an early plateau in $\mathrm{T}^{\mathrm{e}} \mathrm{H}_{2} \mathrm{O}$ and in some studies a rapid fall to $\mathrm{CH}_{2} \mathrm{O}$ while $\mathrm{T}^{\mathrm{c}} \mathrm{H}_{2} \mathrm{O}$ was increasing in the control kidney. This striking contrast with the constricted kidney is further suggestive of a more rapid increase in distal sodium supply and transport in the POK.

Two major proposals may explain the increase in fractional distal sodium supply, transport, and excretion in the postobstructive kidney. An adaptive increase in

\section{HYDRATED}
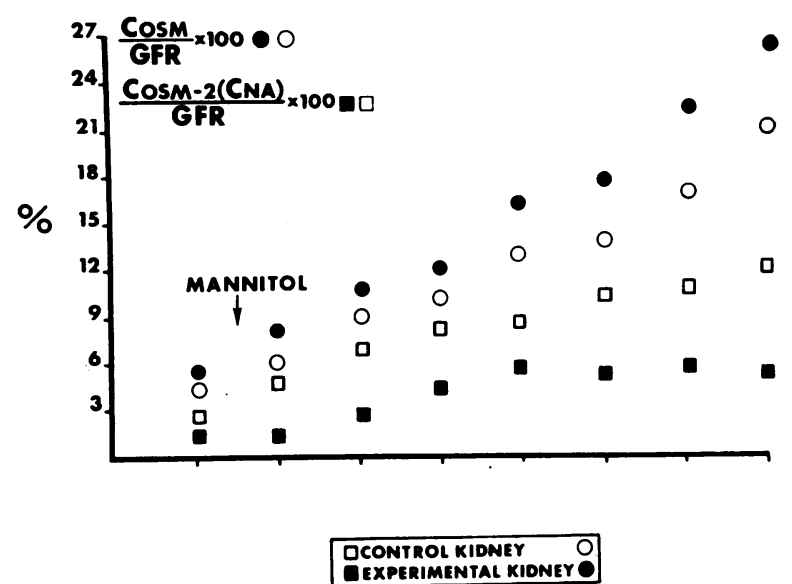

HYDROPENIC

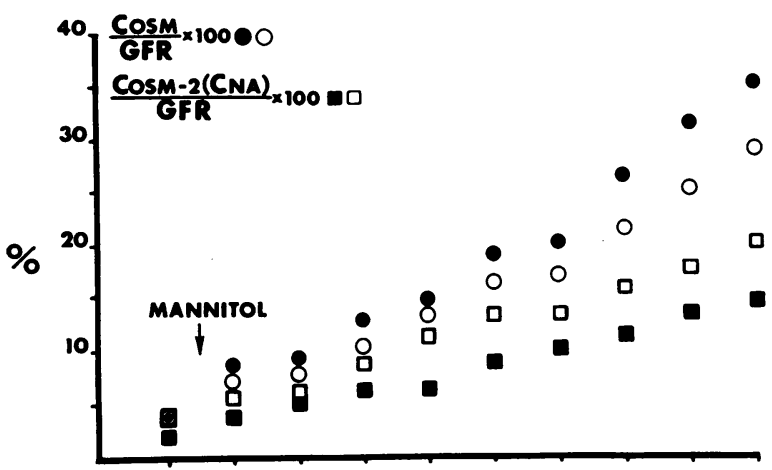

FIgURE 5 Cosm/GFR times 100 and Cosm-2(CNa)/GFR times 100 in postobstructive kidney and contralateral control in a hydrated and hydropenic experiment.

GFR/nephron may decrease fractional proximal sodium reabsorption (22). Alternately, ureteral obstruction may result in a proximal tubular defect which limits the capacity to establish a normal sodium gradient in the presence of nonreabsorbable solute without regard to the level of glomerular perfusion.

Three lines of evidence argue against the proposition that glomerular hyperperfusion may explain these findings. When the fraction of solute excretion attributable to salt is subtracted from total solute excretion and the remaining solute clearance related to GFR, the resultant expression, Cosm-2(CNa)/GFR, is consistently lower on the obstructed side (Fig. 5). This difference appears particularly evident at higher rates of solute excretion. Stated in other terms, the increase in fractional solute clearance (Cosm/GFR) on the postobstructive side seems entirely attributable to increased sodium and re- 
lated anion (salt) excretion (Fig. 5). The rate of excretion of nonreabsorbable solute such as mannitol and other nonsalt solute in relation to GFR is never higher on the experimental side. An element of glomerular hyperperfusion would be expected to produce an increase in all the components of fractional solute excretionmannitol and nonsalt solute, as well as salt-particularly at higher rates of mannitol infusion.

Secondly, glomerular hyperperfusion would be expected to result in glycosuria appearing in the experimental kidney before the control kidney. This did not occur in four glucose experiments in which there was an opportunity to observe initial glycosuria.

Finally, the relationship between the changes in GFR and glucose Tm's in the control and experimental kidney does not support the glomerular hyperperfusion proposal. In the experimental kidney, there occurred a consistent modest fall in glucose $\mathrm{Tm}$ compatible with some decrease in the number of operating nephrons (Table V). However, the simultaneous fall in GFR was proportionately greater in the postobstructive kidney (Table V). The consequent decrease in GFR/glucose Tm on the experimental side suggests a diminished glomerular perfusion per remaining functioning tubular mass. The reason for the difference between GFR/Tm glucose in these studies and the higher GFR/Tm PAH in the kidneys with chronic hydronephrosis reported by Suki et al. (8) is not apparent, but may result from the fact the obstruction in their animals was of longer duration.

It is difficult to be certain that the reduction in glucose Tm indeed reflects a reduced functioning nephron mass since there can be no assurance that the glucose load was sufficient to saturate tubular reabsorptive capacity. However the observation that blood glucose levels exceeded $400 \mathrm{mg}$ per $100 \mathrm{ml}$ in the periods with a low GFR and that glycosuria was present on the experimental side suggests that there was an adequate glucose load. It appears likely that a considerable fraction of the increment in GFR noted in some of the early transitional periods resulted from an increase in the number of functioning nephrons and tubular transport capacity. This may have resulted from the return to perfusion of glomeruli that had dropped out of the circulation during the period of obstruction. The stable GFR and Tm values observed during the steady-state phase of the study suggests that the number of nephrons functioning in the POK throughout the major portion of the experiment remained relatively constant.

These experiments suggest that $24 \mathrm{hr}$ of ureteral obstruction in the dog limits the capacity of the proximal tubule to establish a gradient for sodium reabsorption during a mannitol infusion. Some of the studies, however, show a relative increase in distal sodium supply before the infusion of the mannitol load. Diminished frac- tional proximal sodium reabsorption may thus develop without imposing an osmotic load and a sodium concentration gradient in the proximal tubule. The differences between both kidneys become sharper, however, during the mannitol infusion so that the decreased proximal reabsorption in the experimental kidney is more evident under these conditions.

These data do not exclude a simultaneous defect in distal sodium transport. It was noted earlier that $\mathrm{K}$ excretion, derived in large part from distal tubular secretion is sometimes lower in the POK when absolute sodium excretion is higher. This suggests the possibility that there is some impairment of distal tubular function notwithstanding the fact that an alternate explanation may be valid." Seely and Dirks have recently proposed that a major effect of mannitol in inhibiting sodium reabsorption may occur in the ascending limb of Henle's loop, at least in the hydropenic state (23). Although this observation has not yet been confirmed it is entirely possible that a portion of the augmented sodium excretion in the POK may derive from a site beyond the proximal tubule. The failure for absolute $\mathrm{CH}_{2} \mathrm{O}$ on the experimental side to rise to those levels noted on the normal side when salt excretion is sometimes absolutely higher in the POK hints at some distal limit. It is difficult, however, to anticipate what fraction of the increased distal supply should be absorbed at rising flow rates. Any guess at the extent of a possible distal limit, therefore, seems hazardous.

Several of the major findings presented here such as increased fractional sodium and free water excretion, but diminished $\mathrm{T}^{\mathrm{c}} \mathrm{H}_{2} \mathrm{O}$ formation in the experimental kidney bear an interesting similarity to those reported by Bricker and his associates in some of their studies (24, $25)$. These workers produced a variety of unilateral renal lesions including pyelonephritis and aminonucleoside nephritis. Suki et al. also observed an increase in fractional salt and free water excretion in chronically hydronephrotic dogs (8). The functional similarity in this disparate group of pathological conditions suggests some common unifying feature. Since each pathological state was characterized by a significant loss of functioning nephrons, it may be speculated that this stimulus provokes an adaptive alteration in the residual nephrons by decreasing the sodium reabsorptive capacity of the proximal segment. Such a change in function, by enhancing distal sodium and water supply, would tend to limit progressive salt and water retention. It would also preserve some concentrating ability as well as considerable diluting capacity and would sustain relatively high rates of potassium, titratable acid, and ammonia excretion. The present studies suggest that such an adaptive mechanism may develop within $24 \mathrm{hr}$ without any evident anatomic change. 


\section{ACKNOWLEDGMENTS}

The technical assistance of Mrs. Edith Neubert, Miss Sarah Chipoco, Miss Roberta Yapp, and Mrs. Erna Zehavi is gratefully acknowledged.

The authors are indebted to Dr. Jacob Churg for the Interpretations of light and electron microscopic sections of the control and postobstructive kidneys in two experiments.

This work was supported by the National Heart Institute Graduate Training Grant HTS-5509. Throughout most of the work Dr. Bercovitch was a National Heart Institute Postdoctoral Research Fellow.

\section{REFERENCES}

1. Bricker, N. S., E. I. Shwayri, J. B. Reardan, D. Kellog, J. P. Merrill, and J. H. Holmes. 1957. An abnormality in renal function resulting from urinary tract obstruction. Amer. J. Med. 23: 554.

2. Witte, M. H., F. A. Short, and W. Hollander, Jr. 1964. Massive polyuria and natruresis following relief of urinary tract obstruction. Amer. J. Med. 37: 320.

3. Roussak, N. J., and S. Oleesky. 1954. Water-losing nephritis; a syndrome simulating diabetes insipidus. Quart. J. Med. 23: 147.

4. Earley, L. E. 1956. Extreme polyuria in obstructive uropathy. Report of a case of "water-losing nephritis" in an infant, with a discussion of polyuria. $N$. Engl. J. Med. 255: 600 .

5. Winberg, J. 1959. Renal function in water-losing syndrome due to lower urinary tract obstruction before and after treatment. Acta Paediat. (UPPSALA) 48: 149.

6. Jaenike, J. R., and G. A. Bray. 1960. Effects of acute transitory urinary obstruction in the dog. Amer. J. Physiol. 199: 1219.

7. Berlyne, G. M. 1961. Distal tubular function in chronic hydronephrosis. Quart. J. Med. 30: 339.

8. Suki, W., G. Eknoyan, F. C. Rector, Jr., and D. W. Seldin. 1966. Patterns of nephron perfusion in acute and chronic hydronephrosis. J. Clin. Invest. 45: 122.

9. Stein, R. M., D. D. Bercovitch, and M. F. Levitt. 1964. Dual effects of saline loading on renal tubular sodium reabsorption in the dog. Amer. J. Physiol. 207: 826.

10. Stein, R. M., R. G. Abramson, D. D. Bercovitch, and M. F. Levitt. 1965. Effects of unilateral renal arterial constriction on tubular reabsorption of sodium and water during an osmotic diuresis. J. Clin. Invest. 44: 1720.

11. Orloff, J., H. N. Wagner, Jr., and D. G. Davidson. 1958. The effect of variations in solute excretion and vasopressin dosage on the excretion of water in the dog. J. Clin. Invest. $37: 458$.
12. Suki, W., F. C. Rector, Jr., and D. W. Seldin. 1965. The site of action of furosemide and other sulfonamide diuretics in the dog. J. Clin. Invest. 44: 1458.

13. Goldberg, M., D. K. McCurdy, E. L. Foltz, and L. W. Bluemle, Jr. 1964. Effects of ethacrynic acid (a new saluretic agent) on renal diluting and concentrating mechanisms. Evidence for site of action in the loop of henle. J. Clin. Invest. 43: 201.

14. Earley, L. E., and R. M. Friedler. 1964. Renal tubular effects of ethacrynic acid. J. Clin. Invest. 43: 1495.

15. Goldstein, M. H., M. F. Levitt, A. D. Hauser, and D. Polimeros. 1961. Effect of meralluride on solute and water excretion in hydrated man: comments on site of action. J. Clin. Invest. 40: 731.

16. Porush, J. G., M. H. Goldstein, G. M. Eisner, and M. F. Levitt. 1961. Effect of organomercurials on the renal concentrating operation in hydropenic man: comments on site of action. J. Clin. Invest. 40: 1475.

17. Clapp, J. R., and R. R. Robinson. 1966. Osmolality of distal tubular fluid in the dog. J. Clin. Invest. 45: 1847.

18. Earley, L. E., M. Kahn, and J. Orloff. 1961. The effects of infusions of chlorothiazide on urinary dilution and concentration in the dog. J. Clin. Invest. 40: 857.

19. Goldsmith, C., H. K. Beasley, P. J. Whalley, F. C. Rector, Jr., and D. W. .Seldin. 1961. The effect of salt deprivation on the urinary concentrating mechanism in the dog. J. Clin. Invest. 40: 2043.

20. Goodman, B., J. A. Cohen, M. F. Levitt, and M. Kahn. 1964. Renal concentration in the normal dog. Effect of an acute reduction in salt excretion. Amer. J. Physiol. 206: 1123.

21. Gottschalk, C. W., and M. Mylle. 1959. Micropuncture study of the mammalian urinary concentrating mechanism: evidence for the counter-current hypothesis. Amer. J. Physiol. 196: 927.

22. Bricker, N. S., P. A. F. Morrin, and S. W. Kime, Jr., 1960. The pathologic physiology of chronic Bright's disease. An exposition of the "intact nephron hypothesis". Amer. J. Med. 28: 77.

23. Seely, J. F., and Dirks, J. H. 1969. Micropuncture study of hypertonic mannitol diuresis in the proximal and distal tubule of the dog kidney. J. Clin. Invest. 48: 2330.

24. Bricker, N. S., R. R. Dewey, H. Lubowitz, J. Stokes, and I. Kirkensgaard. 1959. Observations on the concentrating and diluting mechanisms of the diseased kidney. J. Clin. Invest. 38: 516 .

25. Bricker, N. S., S. W. Kime, Jr., P. A. F. Morrin, and T. Orlowski. 1960. The influence of glomerular filtration rate, solute excretion and hydration on the concentrating mechanism of the experimentally diseased kidney in the dog. J. Clin. Invest. 39: 864. 